\title{
The New Synonymy of the Spider Genus Argyrodes (Araneae: Theridiidae) and a Description of a New Species from Japan
}

\author{
Akio Tanikawa ${ }^{1)}$ \\ 谷川明男 ${ }^{1)}$ : イソウロウグモ属（クモ目：ヒメグモ科）の 1 新参 \\ シノニムおよび日本産 1 新種の記載
}

\begin{abstract}
The spider genus Spheropistha Yaginuma, 1957 is newly synonymized with the genus Argyrodes Simon, 1864. A new species of the genus is described from Japan. It can be easily separated from the closely related Argyrodes melanosoma (Yaginuma, 1957), comb. nov. by general appearance.
\end{abstract}

In 1982, Mr. Ken-ichi Kumada collected a male specimen of a unique spider at Kiyokawa-mura, Kanagawa Prefecture. Then Mr. Tomoyuki Kimura and Mr. Akira Shinkai found several females of the same spider at Mt. Kiyosumi, Chiba Prefecture. Recently Dr. Tadashi Miyashita collected many specimens of the spider at Oshika-chô, Miyagi Prefecture. Fortunately I could examine these specimens.

The spider resembles Argyrodes fissifrons O. P.-Cambridge, 1869 in coloration and markings of the abdomen, but is much smaller than the latter. The shapes of genital organs of both the species are much different. Judging from the features of genital organs, the spider in question appears to be closely related to Spheropistha melanosoma Yaginuma, 1957 and Argyrodes incursus Gray et Anderson, 1989. After careful examination, I came to the conclusion that the spider is new to science. It will be described in the present paper.

Judging from the comparison of the features of Spheropistha melanosoma with those of the spiders of the genus Argyrodes Simon, 1864, I came to the conclusion that the genus Spheropistha Yaginuma, 1957 should be included in the genus Argyrodes. The new synonymy will be proposed in this paper.

All the type specimens designated in this paper are deposited in the collection of the Zoological Department, National Science Museum, Tokyo (NSMT).

I wish to express my hearty thanks to Dr. Hirotsugu Ono, National Science Museum (Natural History), Tokyo, for his revising the manuscript of this paper. My sincere thanks are also due to Mr. Ken-ichi Kumada, Miyagi, Mr. Akira Shinkai, Tokyo, Mr. Tomoyuki Kimura, Kanagawa, and Dr. Tadashi Miyashita, University of Tokyo, for their offering valuable specimens used in this study.

1) Shichirigahama Senior High School, 2-3-1, Shichirigahama-higashi, Kamakura-shi, Kanagawa, 248-0025 Japan

神奈川県立七里ガ浜高等学校７248-0025 神奈川県鎌倉市七里ガ浜東 2-3-1

Accepted April 22, 1998 
Genus Argyrodes Simon, 1864, sensu Exline \& Levi, 1962

Argyrodes Simon, 1864, p. 253; Exline \& Levi, 1962, p. 78.

Ariamnes Thorell, 1869, p. 37.

Rhomphaea L. Koch, 1872, p. 289.

Conopistha Karsch, 1881, p. 39.

Spheropistha Yaginuma, 1957, p. 15. SYN. NOV.

Further literatures see Exline \& Levi (1962).

Notes. The genus Spheropistha was described based on the type species $S$. melanosoma by monotypy. Yaginuma (1957) placed Spheropistha in the family Theridiidae. However, Levi and Levi (1962) transferred it to the family Theridiosomatidae. On the other hand, Exline and Levi (1962) considered the genera Ariamnes Thorell, 1869 and Rhomphaea L. Koch, 1872 as junior synonyms of Argyrodes in their large work entitled "American spiders of the genus Argyrodes." In my own judgement, Spheropistha should be included in the genus Argyrodes in the sense of Exline and Levi (1962) as well as Ariamnes and Rhomphoea. They did not mention about the genus Spheropistha in their work, because Levi considered it as a member of the family Theridiosomatidae at that time. Afterward Brignoli (1981) replaced Spheropistha to the family Theridiidae again and kept it as an independent genus. In 1989, Gray and Anderson described from Australia Argyrodes incursus, which closely resembles Spheropistha melanosoma not only in general appearance but also in the features of genital organs. Argyrodes incursus and S. melanosoma should be placed in the same genus.

Yaginuma (1957) mentioned that Spheropistha could be distinguished from Conopistha (=Argyrodes) by the following points: 1) abdomen round, elongation never seen; 2) clypeus shorter than the length of median ocular area; 3 ) median eyes of each row widely separated from each other; 4) colulus long and conspicuous. As I mentioned above, these features are not enough to separate Spheropistha from Argyrodes sensu Exline and Levi, 1962. Spheropistha should be treated as a junior synonym of Argyrodes.

Argyrodes melanosoma (Yaginuma, 1957), comb. nov.

(Figs. 3-5, 7, 9, 11, 13)

Spheropistha melanosoma Yaginuma, 1957, p. 15 (female holotype from Kochi Prefecture, Japan, preserved in Otemon Gakuin University, not examined).- Brignoli, 1981, p. 16.

Specimens examined. 1 우, 30-VIII-1987, 1 우, 9-VII-1988, 2 우, 24-VII-1988 (1 우: NSMT-Ar 3691), 2 우, 24-VI-1990 (1 우: NSMT-Ar 3692), 2 우, 22-VII-1990, Mt. Kiyosumi, Awa-gun, Chiba Prefecture, A. Shinkai leg. 1 우, 24-VII-1988, Kazusakameyama, Kimitsu-shi, Chiba Prefecture, A. Shinkai leg. 1 万', 18-VII-1988, Hadanoshi, Kanagawa Prefecture, A. Shinkai leg. (NSMT-Ar 1693). 1 우, 12-VIII-1992, Ôhara, Iriomotejima Island, Okinawa Prefecture, A. Tanikawa leg. 1 우, 13-VIII-1992, Funaura, same Island and collector (NSMT-Ar 3694). 
Argyrodes miyashitai sp. nov.

(Figs. 1-2, 6, 8, 10, 12)

Specimens examined. Type series. Holotype: ơ, 9-VI-1997, Oshika-chô, Oshikagun, Miyagi Prefecture, Japan (NSMT-Ar 3682). Paratypes: 1 万ొ, 5-VI-1996 (NSMTAr 3683), 1 구, 24-V-1997 (NSMT-Ar 3684), 1 기 2 우, 8-VI-1997 (NSMT-Ar 36853687), 1 우, 10-VI-1997 (NSMT-Ar 3688), same locality as for the holotype. 1 우, same data as for the holotype (NSMT-Ar 3689). 1 万ౌ, 23-V-1997, Kinkazan Island, Oshika-chô, Oshika-gun, Miyagi Prefecture (NSMT-Ar 3690). All the type specimens were collected by Dr. T. Miyashita.

Table 1. Measurement of leg segments of Argyrodes miyashitai sp. nov. (in mm; 기/우).

\begin{tabular}{ccccccc}
\hline Leg & Tarsus & Metatarsus & Tibia & Patella & Femur & Total \\
\hline I & $0.64 / 0.57$ & $1.31 / 1.01$ & $1.19 / 1.05$ & $0.34 / 0.34$ & $1.40 / 1.37$ & $4.88 / 4.34$ \\
II & $0.47 / 0.44$ & $0.55 / 0.56$ & $0.61 / 0.56$ & $0.27 / 0.31$ & $0.87 / 0.85$ & $2.77 / 2.72$ \\
III & $0.34 / 0.34$ & $0.34 / 0.35$ & $0.32 / 0.31$ & $0.21 / 0.26$ & $0.58 / 0.58$ & $1.79 / 1.84$ \\
IV & $0.40 / 0.40$ & $0.53 / 0.56$ & $0.49 / 0.50$ & $0.27 / 0.26$ & $0.87 / 0.98$ & $2.56 / 2.70$ \\
\hline
\end{tabular}

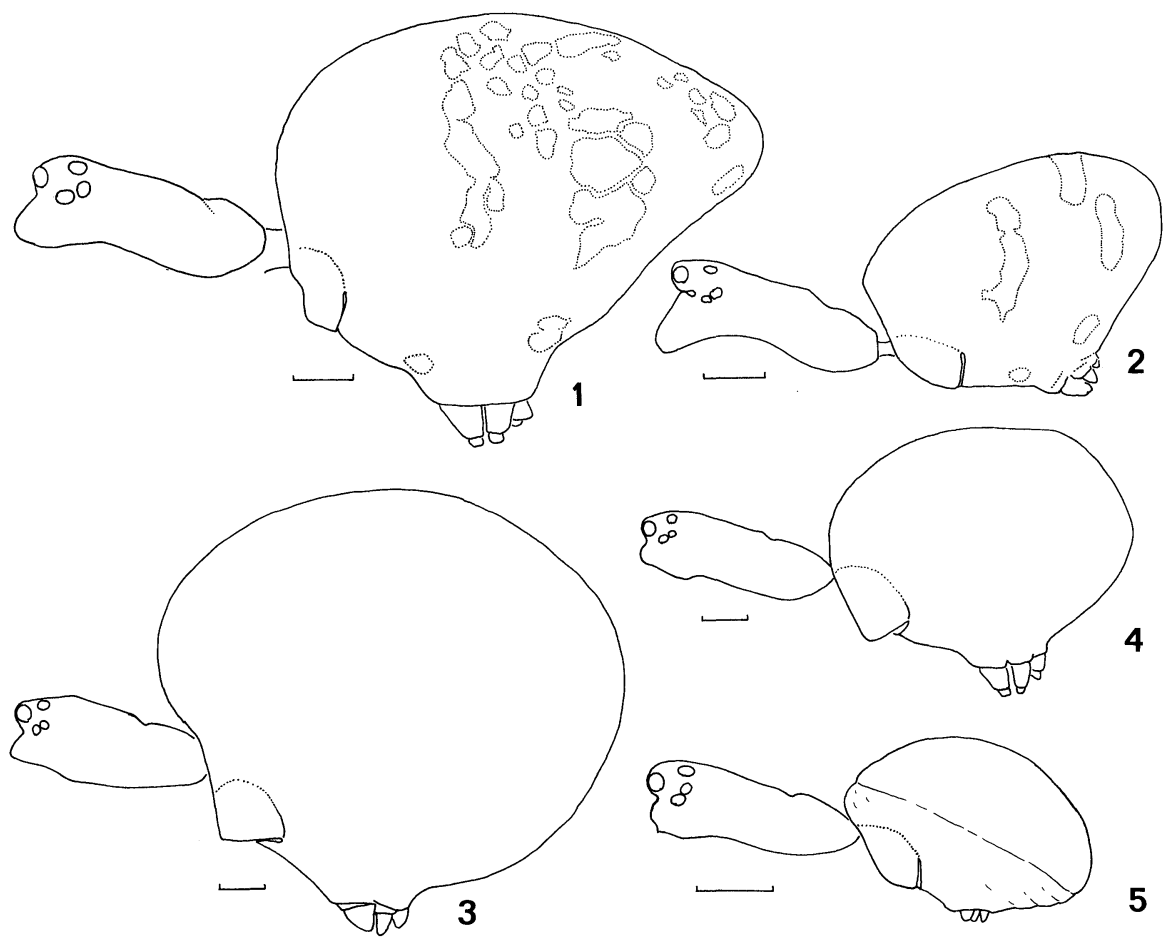

Figs. 1-5. 1-2. Argyrodes miyashitai sp. nov-1. Female, lateral view (NSMTAr 3688). 2. Male, lateral view (NSMT-Ar 3682). 3-5. Argyrodes melanosoma (Yaginuma, 1957)._- - Female after feeding, lateral view (NSMTAr 3691). 4. Female before feeding, lateral view (NSMT-Ar 3694). 5. Male, lateral view (NSMT-Ar 3693). (Scales: $0.25 \mathrm{~mm}$.) 


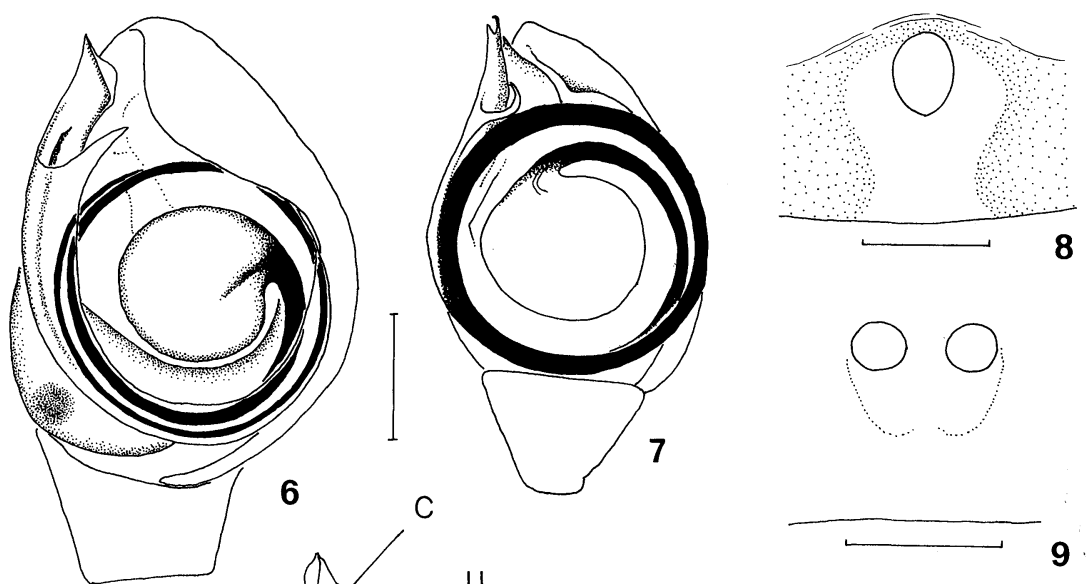

$\mathrm{T} T$
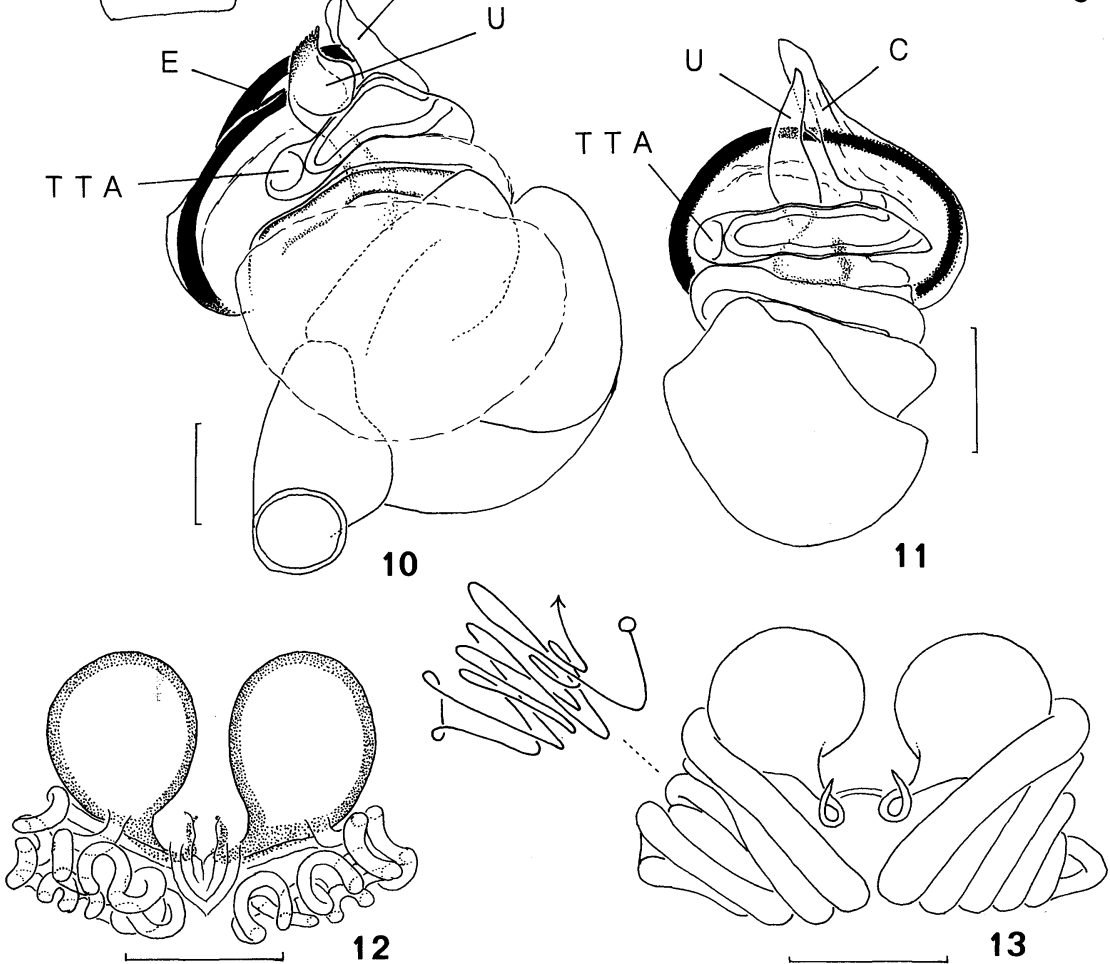

Figs. 6-13. 6, 8, 10, 12. Argyrodes miyashitai sp. nov.—6. Male palp, ventral view (NSMT-Ar 3682). 8. Epigynum (NSMT-Ar 3688). 10. Male palp, expanded (NSMT-Ar 3685). 12. Female genitalia, dorsal view (NSMT-Ar 3689). 7, 9, 11 , 13. Argyrodes melanosoma (Yaginuma, 1957). - Male palp, ventral view (NSMT-Ar 3693). 9. Epigynum (NSMT-Ar 3692). 11. Male palp, expanded (NSMT-Ar 3693). 13. Female genitalia, dorsal view (NSMT-Ar 3692). Abbreviations: $\mathrm{C}$, conductor; $\mathrm{E}$, embolus, TTA, theridiid tegular apophysis; $\mathrm{U}$, unnamed sclerite. (Scales: $0.1 \mathrm{~mm}$.) 
Other specimens examined. 2 ॰ 3juv., 8-V-1997, 1 ð , 8-VI-1997, same locality and collector as for the holotype. 1 + , 22-V-1994, Mt. Kiyosumi, Awa-gun, Chiba Prefecture, T. Kimura leg. 1 శᄁ, 13-V-1982, Ichinosawa, Kiyokawa-mura, Aikô-gun, Kanagawa Prefecture, K. Kumada leg.

Description [based on the male holotype (NSMT-Ar 3682) and one of the female paratypes (NSMT-Ar 3688); variations are given in the parentheses]. Measurement (in $\mathrm{mm})$. Total length or $2.15(2.15-2.60)$, 우 3.10 (2.69-3.10); carapace length $\sigma^{7} 0.96$ (0.95-0.99), 우 $1.05(0.99-1.05)$; width o7 $0.70(0.69-0.75)$, 우 $0.76(0.72-0.76)$; abdomen length or 1.22 (1.22-1.53), 우 2.00 (1.67-2.00), width o o 0.81 (0.81-1.04), 우 1.40 (1.16$1.40)$; height or $1.05(1.05-1.36)$, 우 $1.84(1.53-1.84)$. Length of legs as shown in Table 1.

Male and female: Carapace length/width or 1.37 (1.33-1.44), 우 1.38 (1.38-1.42). Length of leg I/length of carapace or 5.08 (4.93-5.47), 우 4.40 (4.38-4.40). Male palp (Figs. 6, 10): embolus filiform, long, coiled, and wrapped in conductor; conductor long, semicircular; theridiid tegular apophysis (see Coddington 1990) and unnamed sclerite (see Coddington 1990) exist. Abdomen triangular in lateral view (Figs. 1-2), length/ width o 1.51 (1.31-1.51), 우 1.43 (1.40-1.44), height/length o $0.86(0.86-0.98)$, 우 0.92 (0.89-1.00). Female genitalia (Figs. 8, 12): epigynum simple; intromittent canal long, complicated.

Coloration and markings in alcohol. Male and Female: Carapace dark brown. Legs brown. Abdomen dark brown, with silver markings (Figs. 1-2).

Range. Japan (Miyagi, Chiba, and Kanagawa Prefectures).

Remarks. The present new species resembles Argyrodes fissifrons in general appearance, but the latter is much larger than the former. The shapes of epigynum and male palpal organ of these two species are quite different. Judging from the features of both male and female genital organs (Figs. 6-13), this new species appears to be closely related to Argyrodes melanosoma. In both the species, the epigynum is simple (Figs. 89), the intromittent canal is long and complex (Figs. 12-13), the embolus of male palp is very long and coiled (Figs. 6-7), and the conductor of male palp is semicircular (Figs. 6-7). However, the two species can be easily distinguished from each other by the general appearance (Figs. 1-5). Female abdomen of $A$. melanosoma is wholly black except one or two pairs of small silver spots, and almost spherical in shape after feeding (Figs. 3-4), while that of $A$. miyashitai is dark brown with silver markings, and always triangular in lateral view (Fig. 1). Male abdomen of $A$. melanosoma is wholly black except one or two pairs of silver spots, and dorsally sclerotized (Fig. 5), while that of $A$. miyashitai is dark brown with silver markings and not sclerotized (Fig. 2).

Etymology. The species is dedicated to Dr. Tadashi Miyashita, University of Tokyo, who collected the type specimens.

\footnotetext{
摘 要

Spheropistha melanosoma Yaginuma，1957 クロマルイソウロウグモと Argyrodes イソ ウロウグモ属のクモ類とを比較検討した結果, Spheropistha マルイソウロウグモ属をイ ソウロウグモ属から独立させるに十分な特徵を見出すことができなかったので，マルイ ソウロウグモ属をイソウロウグモ属の新参シノニムとし，クロマルイソウロウグモをイ
} 
ソウロウグモ属に移動した．また，日本産イソウロウグモ属の 1 新種を Argyrodes miyashitai ミヤシタイソウロウグモと命名して記載した。本新種は，一見して Argyrodes fissifrons O. P.-Cambridge，1869 チリイソウロウグモに似ているが，本新種の方が体長がは るかに小さく, 雌雄の生殖器の形態は全く異なっている. 生殖器の形態からはArgyrodes melanosoma (Yaginuma，1957) クロマルイソウロウグモに近縁であると考えられる．本 新種とクロマルイソウロウグモとは腹部の形や色彩などの違いによって簡単に見分ける ことができるが, 両者の生殖器の構造には次のような共通点が見られる. 外雌器の構造 が単純であること；交尾管が長くて複雑に曲がりくねっていること；雄触肢の移精針が たいへん長くてコイル状に丸まっていること；指示器が半円状でその中に移精針を包ん でいること.

\section{References}

Bonnet, P., 1955. Bibliographia Araneorum, 2(1), pp. 1-918. Toulouse .

Brignoli, P. M., 1981. Spiders from the Philippines IV. A new Ogulnius and notes on some other Oriental and Japanese theridiosomatidae (Araneae). Acta arachnol., 30: 9-19.

Brignoli, P. M., 1983. A Catalogue of the Araneae Described between 1940 and 1981. 755 pp. Manchester University Press, Manchester and New York.

Coddington, J. A., 1990. Ontogeny and homology in the male palps of orb-weaving spiders and their relatives, with comments on phylogeny (Araneoclada: Araneoidea, Deinopoidea). Smithson. Contrib. Zool., (496): 1-52.

Exline, H. \& H. W. Levi, 1962. American spiders of the genus Argyrodes (Araneae Theridiidae). Bull. Mus. comp. Zool., 127:75-202, 14 pls.

Gray, M. R. \& G. J. Anderson, 1989. A new Australian species of Argyrodes Simon (Araneoidea: Theridiidae) which preys on its host. Proc. Linn. Soc. N. S. W., 111: 25-30.

Karsch, F., 1881. Diagnoses Arachnoidarum Japoniae. Berl. ent. Zeits., 25: 35-40.

Koch, L., 1872. Die Arachniden Australiens, nach der Natur beschrieben und abgebildet, pp. 105-306. Nürnberg.

Levi, H. W. \& L. R. Levi, 1962. The genera of the spider family theridiidae. Bull. Mus. comp. Zool., 127: $3-71,14$ pls.

Platnick, N. I., 1989. Advances in Spider Taxonomy, 1981-1987. 673 pp. Manchester University Press, Manchester \& New York.

Platnick, N. I., 1993. Advances in Spider Taxonomy, 1988-1991. 846 pp. New York Entomological Society \& The Anrerican Museum of Natural History, New York.

Simon, E., 1864. Histoire Naturelle des Aranignèes (Aranèides). 540 pp. Roret, Paris.

Thorell, T., 1869. On European spider. Part I. Review of the European genera of spiders, preceded by some observations on zoological nomenclature. N. Act. reg. Soc. sci. Upsal., (3)7: 1-108. (not seen.)

Yaginuma, T., 1957. Two new conopisthine spiders from Japan. Acta arachnol., 15: 11-16. 